\title{
SPEECH ACT ANALYSIS OF JACINDA ARDERN ABOUT COVID-19
}

\author{
Husein Furqani Attamimy ${ }^{1}$, Esti Junining ${ }^{2}$, Ismatul Khasanah ${ }^{3}$ \\ Linguistics Department. Universitas Brawijaya Malang. Indonesia \\ husein.furqoni96@gmail.com ${ }^{1}$, ismatulkh@ub.ac.id ${ }^{2}$,esti@ub.ac.id ${ }^{3}$
}

\begin{abstract}
This study attempts to analyze the illocutionary act of Jacinda Ardern speech by using Fairclough's Critical Discourse Analysis. The data of this study is a video transcript of Jacinda Ardern's speech on policies regarding Covid-19 which she delivered on Mar 22, 2020. The data analysis of the study is a descriptive study using Fairclough's theory of discourse analysis. The result shows that it is known that the types of speech used in Ardern's speech are representative and commissive illocutionary speech. From the point of view of Fairclough's discourse analysis, Ardern's utterances tend to use language that is straightforward, concise and easy to understand. Her utterances do not use figurative language that might be used to disguise the real language of the situation at hand. The language used by Ardern tends to be straightforward and reveal facts that occur in the field and provide sufficient explanation for the consequences that will occur in the future. However, on the other hand, she can choose good words so that people's worries do not get bigger. She can also control and reduce public concern by giving a statement about the actions that the government will take to tackle the coronavirus.
\end{abstract}

Keywords: critical discourse analysis, speech act, speech

\begin{abstract}
ABSTRAK
Penelitian ini mencoba menganalisis tindak ilokusi tuturan Jacinda Ardern dengan menggunakan Analisis Wacana Kritis Fairclough. Data dalam penelitian ini adalah transkrip video pidato Jacinda Ardern tentang kebijakan terkait Covid yang disampaikan pada tanggal 22 Maret 2020. Teknik analisis data yang digunakan dalam penelitian ini adalah deskriptif analisis dengan mengaplikasikan teori Fairclough tentang analisis wacana. Berdasarkan pembahasan bahwa jenis tuturan yang digunakan dalam pidato Jacinda Ardern adalah tuturan ilokusi representatif dan commissive. Dari sudut pandang analisis wacana Fairclough, tuturan-tuturan Ardern cenderung menggunakan bahasa yang lugas, singkat dan mudah dimengerti. Tuturan Ardern tidak menggunakan bahasa bermakna kiasan yang mungkin dapat digunakan untuk menyamarkan bahasa sesungguhnya dari situasi yang sedang dihadapi sekarang. Bahasa yang digunakan Ardern cenderung lugas dan mengungkap fakta yang terjadi di lapangan serta memberikan penjelasan yang cukup atas konsekuensi yang akan terjadi nanti. Namun di satu sisi, dia dapat memilih kata-kata yang baik sehingga kekhawatiran masyarakat tidak semakin besar. dia juga dapat mengontrol dan mengurangi kekhawatiran masyarakat dengan memberikan pernyataan tentang aksi-aksi yang akan segera dilakukan pemerintah dalam menanggulangi coronavirus.
\end{abstract}

Kata kunci: analisis wacana kritis, tindak tutur, pidato

\section{INTRODUCTION}

Humans, with their superiority, can change from time to time to become the perfect creature. One of their strengths is that they can use language. Language is indeed just a symbol that the speaker uses to inform his/her thoughts to others. Nevertheless, if it is used in interaction, it is very powerful. It can make the listener do what the speaker wants (Kurniati et al, 2015). Besides, the language uttered can also make the listeners angry, pleased, and proud. The language has the power which 
is only possessed by a human. It can work as people can do (Kurniati et al, 2015).

The success or the failure which comes to people's lives may occur because of their language. If they can use language, either written or oral, they often gain what they want. By language, they can make friends, so that they can enjoy better lives. On the contrary, if their language is poor, they cannot do anything with the language. Even though they are smart, they will not be considered in any positions in society. Moreover, they may get into trouble for being isolated from their society (Hossain, 2015).

People have to be able to use language accordingly, especially in speech. Speech is the ability to speak in front of the public to express their opinion or give an idea about something important. An idea can be conveyed appropriately in a speech using good language that the audience can easily understand. The purpose of speech is not only to convey words or sentences, but also it can give an effect to the listener. When humans deliver a speech, they want to give benefit or information to the listener (Kurniati et al, 2015).

Language is not only a set of systemic alphabets spoken by humans, but the language is also an action that has an impact. These actions are then called speech acts. (Austin, 2018) was the first to convey speech acts. A speech act is a speech that contains action in communication by considering the speech's context and situation. When a person speaks, many factors must be addressed, such as who is spoken (speaker), about whom the speech is delivered (speech partner), the intent of the speech (the intention of the speaker), and the effect (impact) of the speech. As a speaker, three actions are taken while communicating, including a) locutionary acts, (b) illocutionary acts, and (c) perlocutionary acts (Austin, 2018).

Locutionary acts are acts of saying something. For example: "I'm hungry." The locus meaning of the statement is if "I" (the statement maker) is hungry, or on an empty stomach, it does not mean to ask for food or ask if there is food. So the meaning of locus is the real meaning. Illocutionary acts are taking the action of saying something. For example: "This room is so hot." The illocutionary meaning of the statement might be asking to turn on the fan, open a window, or ask whether it is permissible to undress (Austin, 2018). If the statement is repeated, it is a complaint or a request. Therefore, meaning of illocution is the implied meaning (the meaning contained) in a speech that requires an answer or action. Perlocutionary acts are actions that occur to a speech partner as a result of the influence of a speech. Example: A teacher gives his students assignments, after which he says, "This rattan is strong." The meaning of perlocution in the statement is that a teacher (speaker) gives influence (fear) to his students (speech partners) so that they do not forget to complete the homework he is given (Austin, 2018). 
To analyze the speech, Critical Discourse Analysis can be used. Critical Discourse Analysis (CDA) is a type of discourse analysis research that primarily studies the way social power abuse, dominance, and inequality are enacted, reproduced, and resisted by text and talk in the social and political context. With such dissident research, critical discourse analysts take an explicit position, and thus want to understand, expose, and ultimately resist social equality (Dijk, 2014). The object of $\mathrm{CDA}$ is public speech, such as advertisements, newspapers, political propagandas, official documents, laws and regulations, and so on. It aims to explore the relationships among language ideology, and power. One of the objects of research that is often studied using discourse analysis is speech.

Jacinda Ardern is one of the leaders that can handle COVID-19 problems well. Jacinda Ardern is the Prime Minister of New Zealand that brings the worlds' praise to New Zealand since the spread of COVID-19 in New Zealand is under control. Different from the other countries that have to wait long enough to take action because of the social and economic considerations, New Zealand takes hard and early action to control COVID-19. Jacinda Ardern took hard action by applying for the national shutdown in March and April. This decision was later credited with vanquishing the virus in New Zealand. This 100 days shutdown was one of the strictest shutdowns in the world (Graham-McLay, 2020). In her speech, Jacinda Ardern has her way to deliver the solution to prevent the country's chaos. Rather than use indirective and motivational language to the soothe citizen, her speech was concise and to the point that contains much information about what to do at the time. There are several previous studies on similar topics. The study conducted by (Wang, 2010) aims to analyze the speech of Barack Obama using critical discourse analysis. This study shows that Barack Obama used short and straightforward sentence features in delivering his speech. The second previous study is conducted by (AlMajali, 2015) to analyze salient linguistic features of the ousted Arab presidents' political speeches during the Arab Spring Revolution. The results of this study revealed that the political speeches which were delivered during the Arab Spring Revolution have their distinctive features, which are different from those The third previous study is conducted by Sharififar and (Rahimi, 2015) that analyze Obama's and Rouhani's political speeches at the UN in September 2013. The study revealed that Obama had applied a colloquial language, consisting of simple words and short sentences that are understandable to different people. However, Rouhani has used more difficult words, and his language is relatively rigid and formal. Those previous studies are different from this study. The first previous and third studies use Halliday Systemic Functional Grammar; the second previous study focuses on cohesion. It uses Halliday and Hasan's theory, while this study uses Fairclough's analysis. 
Thus, this study attempts to analyze Jacinda Ardern's speech using Critical Discourse Analysis. The researcher decided to employ Fairclough's critical discourse analysis theory because it is worth to be used since it is rarely applied in speech act analysis. Besides, it is also interesting to study Ardern's speech since she can deliver her message well and influence her people well through her speech. She can influence her people well and make them obey her that results in the success of New Zealand controls Covid-19 spread. This study will contribute to linguistics studies, especially in applying the critical discourse analysis framework in the speech act.

\section{LITERATURE REVIEW}

\section{Critical Discourse Analysis}

Discourse is an attempt to expose the secret motives of a subject which makes a declaration. Speech is carried out by putting oneself in a speaker's position with interpretation following a speaker's meaning structure. In a linguistic context, speech is a unit of language that is larger than a word. The use of language in conversation, both verbally and in writing, is discourse (Eriyanto, 2011).

Critical discourse analysis is an analysis whose use is aimed at analyzing language using the critical language paradigm. In critical discourse analysis, discourse is not only understood as a study of language. Even though in the study of critical discourse analysis using language in the text to be analyzed, the results obtained are not to get an overview of the linguistic aspect, but to be able to relate to the context (Darma, 2014). The study of critical discourse analysis can help understand the language in its use because language is useful as a means of communication. Through language, everyone can produce meanings that occur in social life (Darma, 2014).

In critical discourse analysis, language is not understood as the study of language. However, in the end, this critical discourse analysis uses language in the text as material for its analysis. However, the language analyzed here is slightly different from language studies in the traditional linguistic sense. Language is analyzed not by describing solely from linguistic aspects but also by relating it to context. Furthermore, the context here means that the language is used for specific purposes and practices, including power practice. According to (Fairclough, Mulderrig, \& Wodak, 2013) critical discourse analysis sees discourse from the language in speech and writing as a social practice. Describing discourse as a social practice causes a dialectical relationship between certain discursive events and the situations, institutions, and social structures that shape them.

\section{Fairclough Critical Discourse Analysis}

(Fairclough, 1992) uses a detailed intellectual analysis to understand how a 
discourse process works through the linguistic elements in a text. However, Fairclough also argues that textual analysis alone is insufficient to analyze a discourse because it cannot explain the relationship between text, structure, and social and cultural processes. In order to combine both textual and social analysis, perspectives from various fields are needed. Fairclough argues that macro-sociological analysis can see that social structures and power relations shape social practices. In contrast, interpretive traditions can see how society is actively involved in making the world of rules in everyday life. Fairclough's theory centers on how discourse is constructed, and the world is constructed. The concept of discourse, according to Fairclough, can be applied in three different ways (Fairclough, 1992). The first, most abstract concept is a discourse, which uses language in social practice. The second concept of discourse is that discourse is a type of language used in specific fields such as political discourse or scientific discourse. The third concept, discourse, is seen as a way of speaking that explains an experience through a particular point of view, for example, a feminist discourse, a communist discourse, a workers discourse, and so on (Fairclough, 1992).

(Fairclough, 1992) presents a discourse model comprising three dimensions of discourse study: text, discourse practice, and socio-cultural practice dimensions. (a) The text (microstructural) dimensions are linguistically analyzed: by looking at vocabulary, grammar, and syntax. (b) Discourse practice (mesostructure) is a factor relating to the process of text creation and consumption. (3) A factor relevant to contexts outside the text is socio-cultural practice (macrostructural) (Eriyanto, 2011). Three different levels of analysis are then used to examine the three dimensions: (1) the definition is used to examine the document, including continuity and coherence, grammar and diction; (2) the interpretation is used to analyze the interpretation of the text, including development, delivery, and consumption. Texts and (3) examples are used to examine socio-cultural patterns at the level of circumstances, organizations, and cultures (Fairclough, 2013).

\section{Speech Act}

People create utterances containing grammatical structures and words to communicate them, but they also perform acts through those utterances. The actions performed through utterance are called acts of speech. The speaker typically expects the hearer to understand his or her communicative intent. There is some meaning of speech act from some sources here that will be clarified.

According to (Nunan, 2015), speech acts are simply things that individuals do by words, such as "apologizing," "complaining," "instructing," "agreeing," and "alert." Besides, (Nunan, 2015) notes that it is only possible to classify speech acts performed by a single utterance if we consider the context in which utterance takes 
place.

According to (Demes \& Adrian, 2001), in uttering expressions, the speech act is done. Theorists found no suitable terminology already available for marking various forms when they started researching speech acts, so they had to invent one. Almost everyone uses utterances to express the message in everyday life. Simultaneously, the message is often communicated by using gestures or even merely by staying silent.

Furthermore, acts performed by utterance are, according to (Yule, 1996), speech act. More precise labels, such as apology, complaint, praise, invitation, pledge, or request, are commonly given in English. For instance, if a boss has much control in a situation, then the utterance of the phrase fired by the boss is more than just a comment. It indicates a kind of order. A speech act is also used in many newspapers, movies, novels, dramas, short stories, and ads.

Social behavior performed by utterances is speech acts. Besides, according to (Austin, 2018), all cultures use speech acts to perform social functions, and there are some performative verbs in most languages that specifically reflect the act of speech, such as apologies, accusation, order, pledge, and so on. The speech act is typically performed in a situation that offers contextual elements that help understand the speaker's intention. For example, a person says 'it's very cold in here' in a room with an open window. This expression means an order for anyone near the window to shut the window. This utterance can also easily be interpreted as a request to close the window by the interlocutor. Moreover, when these intentions are not explicitly specified, contextual and social knowledge helps interactors perceive each other's intentions.

According to (Yule, 1996), on any occasion, the action performed by producing an utterance will consist of three related acts. The first is the locutionary act, which is the basic act of utterance or producing a meaningful linguistic expression. For example, "I am hungry", this utterance is a basic description of the speaker. The second is the illocutionary act, is when acts as a request, and the illocutionary act has the intended meaning. For example, "please give me some food", this utterance has a meaning from the utterance that states from the speaker. The third is the perlocutionary act, which is the effect 14 the act has on the addressee. Here, the hearer will do what the speaker states to the hearer. The example above will give the impact of locutionary and illocutionary. So, the hearer will prepare or take something that can be eaten by the speaker. From the kinds of different speech acts, we know how the utterance has different meanings. The actions that are done by the hearer is the impact of the utterance that is stated by the speaker. Speech acts can be classified according to how they affect the social interaction between speaker and 
hearer.

Linguists have classified the Speech Act. Three stages of behavior beyond the act of utterance are defined by (Austin, 2018).

a) Locutionary Acts

The act of location is the nature of the words spoken or the fundamental act of utterance. (Austin, 2018) notes that the locutionary act is roughly equivalent to uttering a certain meaning and reference phrase, which in the conventional sense is again roughly equivalent to meaning. (Leech, 1996) states that the act of saying something is executed through locutionary actions.

b) Illocutionary conduct

Illocutionary behavior is the role of the words spoken by the speaker. (Austin, 2018) describes illocutionary conduct as an expression that has a certain (conventional) influence. (Leech, 1996) also notes that in saying something, the illocutionary act executes the act.

There are five essential forms of illocutionary acts:

1) Representative: representative speech acts are utterances that bind the speaker to the reality of a given proposition.

2) Directive: Directive is utterances that try to get others to do something. The point is to guide the listener to do something that has a suitable word-to word direction.

3) Commissives: commissions act commits the speaker to do something in the future with a word-to - word match direction; the proposition is a future act by the speaker in which an intention is conveyed.

4) Expressive: Expressive act is utterance that communicates the inner state of the speaker against a certain entity.

5) Declarations: Declaration act is performed by someone who, under some institutional context, is specially allowed to do something.

c) Perlocutionary act

Perlocutionary act is the sense of the phrase for the listener. The perlocutionary act of (Austin, 2018) is the effect of an utterance. It is what individuals bring about or accomplish by saying things like compelling, compelling, deterring, and even telling, shocking, misleading. (Leech, 1996) determines that, by saying something, the perlocutionary act executes the act. 


\section{RESEARCH METHOD}

In a study, a researcher needs a method to be used as a foothold in carrying out his research step by step. In this study, researchers used qualitative research methods. (Setiadi, 2010) explains that qualitative research is research on understanding social problems or human problems, which is based on developing a complex and holistic picture, described in words that describe the details of the opinion or view of the data source.

This study's data is a video transcript of Ardern's speech on policies regarding Covid, which she delivered on Mar 22, 2020. The video is accessed from Youtube, with the keywords: Ardern's speech on covid-19. The research procedure in this study begins with the researchers transcribing the video before conducting the analysis. In this study, the researcher described the reporting of speech acts using a critical discourse analysis knife or Critical Discourse Analysis (CDA) with Norman Fairclough's analysis model. CDA, which is a form of critical paradigm, refers more to interpretation. With interpretation, we will get the world inside, enter into the text, and reveal the meaning behind it (Eriyanto, 2011). The validity of the data is carried out to prove whether the research carried out is genuinely scientific research and test the data obtained. The validity test of the data in this study is by triangulation of sources. To ensure that the data is credible, the information and data have been obtained through several sources. The data obtained were analyzed by researchers to produce a conclusion.

\section{FINDINGS AND DISCUSSION}

\section{Illocutionary Acts in Jacinda Ardern Speech viewed from Fairclough Discourse Analysis}

In her speech regarding COVID-19, Jacinda Ardern used a distinctive speech act to convey its influence to listeners. This speech can be analyzed using Fairclough's discourse.

(1) We are fortunate to still be some behind the majority of overseas countries, in terms of cases, but the trajectory is very clear. Act now or risk the virus taking hold as it has elsewhere.

The utterance (1) is categorized as representative illocution since it stated the speaker's beliefs. The speaker believes that New Zealand is quite lucky at the time because the virus is still in the early stage. The number of viruses spread is not as many as in the other countries. However, she also believes that this condition must not be taken lightly. New Zealand must take action immediately before it is too late as what happens in other countries. Then this utterance, when viewed from the Fairclough approach, in the text analysis, the above speech uses straightforward and 
clear words without any figurative words. This is intended so that listeners can immediately understand its meaning. When associated with social institutions, these speeches are produced to direct the community's mindset and provide motivation. The word "we are fortune" indicates that the speaker wants to motivate New Zealand to have more hopes of successfully controlling the virus than other countries. However, after that sentence, another sentence is embedded that invites the listener to choose "act now or risk the virus taking hold as it has elsewhere," reminding the listener not to lose their guard.

(2) We currently have 102 cases, but also Italy once now the virus has overwhelmed their health system, and hundreds of people are dying every day.

The utterance (2) is categorized as representative illocution because it shows the facts in the form of an image of a phenomenon. This speech does not mean to order or ask but to inform a critical case, namely about the number of coronavirus cases in New Zealand. Then this utterance, when viewed from the Fairclough approach, in the text analysis, the language used is logical, scientific, and easy to understand. The addition of the statistics at the beginning is intended to make the speech look more convincing. When viewed from social and situational practices, from the above narrative, Jacinda Ardern tries to educate the public about the language of the coronavirus by taking an example from the cases that occurred in Italy.

(3) We have always said that we would act early, decisively, and go hard, and we will

The utterance (3) is categorized as a commissive speech act since it commits the speaker to do something in the future with a word-to-word direction of fit. An intention is expressed; the proposition is a future act done by the speaker. In this case, the speaker commits to take massive action in dealing with COVID-19 immediately. The speaker said that back then when the virus did still not reach the country, the government would take early action. This utterance is made to explain that the promise will be implemented. Then this utterance, when viewed from the Fairclough approach, in the text analysis, the speech uses light and easy to understand language and is brief and does not use any scientific terms. When viewed from a social and situational perspective, the speech aims to calm and control the community. These remarks indicate that the government is working hard to tackle the coronavirus and that the government's promises will be implemented soon.

(4) We have two cases where public health officials have been unable to find how they came in contact with Covid-19, on that basis, we now consider there is transmission within our communities. If community transmission takes off in New Zealand the number of cases will double every five days. 
The utterance (4) is categorized as representative illocution because it shows the facts in the form of an image of a phenomenon. This speech does not mean to order or ask but to inform a critical case. In this utterance, Jacinda Ardern wants to inform and give New Zealander people an insight into the possibility of community transmission, which is very dangerous because after it happens, the number of cases doubles every five days. Based on Fairclough's analysis, when viewed in terms of text, the utterance used by Ardern contains a straightforward message to make people more cautious about their condition. From the above utterance, Jacinda Ardern, as a country leader, has a significant role in educating and leading New Zealander when viewed from social and situational practices. She let the people know about the fact that happens in their country that the Covid-19 has spread and it can be worse. Thus, as a leader, she uses her position to educate people on how fast it can spread and the consequences of community transmission.

(5) Gatherings, indoors or out, and of any shape or size, must be cancelled. This means weddings, birthday celebrations and other gatherings. Workplaces should have everyone working from home.

The utterance (5) is categorized as directive speech acts because it is expressed to order. The utterance delivered by the speaker (Jacinda Ardern) to the hearers is to give an order. The utterance contains New Zealand people's orders to avoid all kinds of gatherings from indoors to out, including people celebration days such as weddings and birthday celebrations. Ardern also gives direct orders to all employers to shift their work model offline to online (working from home). This utterance is categorized as directive since it deals with giving an order. It means to make the hearer do as the speaker says. The hearer, in this case, is all citizens of New Zealand. In this case, the speaker (Jacinda Ardern) wants the hearer to do what she wants (cancel all kinds of gatherings). Then this utterance, when viewed from the Fairclough approach, in the text analysis, the above speech uses straightforward words since the utterance is an order. This is intended so that listeners can understand the order well. When associated with social institutions, these speeches are produced to give firm order that must be obeyed by all New Zealand people.

(6) I understand that self-isolation is a daunting prospect, You can leave your home for fresh air, a walk, exercise. To take your children outside. But remember the simple principle. It must be solitary.

The utterance (6) is categorized as directive speech acts because it is expressed to order. The utterance delivered by the speaker (Jacinda Ardern) to the hearers is to provide order in the form of advice. The intention of giving advice is to make the hearer do as the speaker said in her direction. This utterance is categorized 
as directive since it deals with giving an order. It means to make the hearer do as the speaker says. The hearer, in this case, is all citizens of New Zealand. In this case, the speaker (Jacinda Ardern) wants the hearer to do what she wants. She gives people several options. She emphasizes the order is only about avoiding crowds so that people still can be outside when they are in solitary. Then this utterance, when viewed from the Fairclough approach, in the text analysis, she constructs her sentences as well as possible so that it seems like she does not force people to stay inside every day. She shows her sympathy and tries to soothe people's worries by saying that they can still be outside if they avoid crowds. When associated with social institutions, as a country leader, she has a significant role to control the overall situation. It seems that she is able to smooth talk, she gives an order to stay inside and avoid the crowd in a right way, she does not use strong order words that can trigger people anxiety or fear.

(7) We are asking that you only spend time with those you are in self-isolation with. And if you are outside, keep your distance from others. That means 2 meters at all times. This is the single most important thing we can do right now to stop further community transmission

The utterance (7) is categorized directive speech acts because it is expressed to give an order. The utterance delivered by the speaker (Jacinda Ardern) to the hearers is to give order in the form of instruction. The main instruction of the utterance is about the importance of keeping distance. Ardern emphasizes that since Covid-19 transmission is massive, it is essential for people to maintain their distance. People can be close to only with the person they have self-isolation with to prevent and stop community transmission. Then this utterance, when viewed from the Fairclough approach, in the text analysis, she gave the order to New Zealand people politely by using the word "asking." Different words make different perceptions and impressions. She uses more gentle words that indicate the good will of the government. By asking rather than commanding the people, she indicates that the government is asking for people's cooperation and help, not demanding and forcing people to obey the order. In social context, as the leader, she has to be able to use the appropriate language to embrace her people well. The utterance above is the implication of her effort to communicate well with the people.

\section{Discussion}

Speech act is a theory that attempts to examine the meaning of language based on speech's relationship with the speaker's action. The study is based on the view that (1) speech is the main target of communication and (2) new speech has meaning if it is realized in a real communication act, for example, making statements, questions, 
orders, and requests (Rusminto, 2015).

The speech act of the speaker is the actual event in the speech situation. Speech acts are individual symptoms, are psychological, and their survival is determined by the speaker's language ability in dealing with specific conditions (Chaer, 2010). Chaer also revealed that the speech event is the occurrence or continuation of linguistic interaction in one form of utterance or more involving two parties, namely the speaker and interlocutor with one subject at a particular time, place, and situation. Thus, in realizing speech, someone does something called action performance. Speeches in the form of performance of these actions are referred to as performative utterances, intended to act. Speech act studies are more oriented towards someone when they become a speech partner. When becoming a speech partner, he must understand the speaker's speech acts because speech is not always direct and literal. An understanding of speech acts is needed to find out the true meaning of the spoken utterances so that communication can run smoothly.

Illocutionary act is performed in saying something and includes betting, promising, denying, stating, promising, apologizing, threatening, predicting, ordering and requesting, and ordering, some of the verbs to label illocutionary acts can themselves be used performatively. Moreover, illocutionary act can be defined as what the speaker intends to do by uttering a sentence. In other words, it is the out in saying something using a certain intention. (Coulthard, 1977) states that basically, an illocutionary act is a linguistic act performed in uttering a certain word in a given context. The most significant activity level in a speech act is the illocutionary act because the force, which has been desired by the speakers, determines this act. Illocutionary act can be the real description of the interaction condition.

From the result, viewed from speech act theory, it can be seen the real meaning of Ardern utterances. Illocutionary acts that Ardern used in her speech are representative, commissive and directive. Each utterance has different purposes and meaning. She uses many representative acts since she prefers to say the truth to her people rather than use sweet talk and say that everything will be under control like the leader of other countries. The commissive speech act uttered by Ardern is to show her people that she is committed to solve covid-19 problems in her country. While in directive speech acts, she gave direct order for the citizens to do several covid-19 protocols. Also, in delivering her order, several times, she uses indirect command words such as "asking." When asked for citizen cooperation, she also expresses sympathy like saying that she understands that it is a difficult condition for her citizens.

Beside the theory of speech act, the real meaning of utterance can also be interpreted by applying discourse analysis. Fairclough connects the discourse with 
others' meaning behind it (Eriyanto, 2011). It can be analyzed in the term of text and socio cultural practices. Text is used as a form of representation of something that contains a certain ideology. The text is dismantled linguistically because it wants to see how a reality is displayed or formed in the text which may lead to a certain ideology, how the writer constructs his relationship with the reader (either formally or informally, closed or open), and how an identity is to be displayed (the identity of the author and the reader), meaning that in this text analysis includes representations, relationships, and identities. Socio-cultural practice is a dimension related to contexts outside the text. Like the context of the situation. Contexts related to society, or culture, and certain politics that affect the presence of the text.

Discourse sees language is always involved in power relations, especially in the formation of subjects and various representational acts in society. (Gee, 2011) reinforces this by stating that forms of power affect language and in terms of power can operate ideologically through language that can function to regulate certain domains. This is how critical discourse analysis works not only to say something but to do something. People use language to communicate, cooperate with, help others, and build things like marriages, reputations, and institutions. However, language is used to lie, benefit oneself, hurt people, and destroy things like marriage, reputation, and institutions. This means that the discourse analysis approach is not near related to language alone but concentrates on ideas, problems, and themes expressed in speech and writing.

In critical discourse analysis, language is considered a discourse and a form of social action that creates and changes the world as well as a form of social action that has historically and culturally emerged in dialectical relationships with other social practices. Discourse contributes significantly in creating unequal social power relations among various existing social groups. (Fairclough, 2013) defines discourse in three different ways. First, in the most abstract sense, discourse is defined as the use of language as a social practice. Second, discourse is defined as a type of language used in certain fields, such as political discourse, scientific discourse, and so on. Third, in the most concrete sense, discourse is used to designate ways of speaking that give meaning to experiences from a certain perspective.

Discourse is a form of social practice that constructs the social world, identity and social relations. In addition, the existence of discourse is dialectically related and shaped by other social structures. Discourse produces knowledge and social practice and the power relations inherent in it. Discourse also shapes subjectivity by defining the body, mind, and life of the subject. Power systems in turn create subjects by regulating their lives through a series of restrictions, prohibitions, regulations, controls, or even individual protection related to political structures. These subjects 
are formed, defined, and reproduced according to this structure. In turn, rules are discursively created, disseminated, and institutionalized to ensure that the subject meets and conforms to social, cultural, and political necessities in its social cognition and practice.

Ardern's speech did not escape the culture and general outlook in New Zealand. New Zealand is geographically isolated in the Pacific Ocean, and this can provide a sense of removal from pressing global political issues. Nevertheless, its people are very globally minded and most have a strong aspiration to travel. It has become almost a rite of passage for people to gain overseas experience, with many taking advantage of easy migration opportunities to the UK or Australia (Kennedy, 2012). New Zealanders generally see themselves as being open-minded towards new ideas, difference, and change. Society is underpinned by strong egalitarian beliefs that everyone should have an equal opportunity to better their circumstances regardless of their background. Financially successful people are not viewed as being better than anyone else - rather, those who are privileged are simply acknowledged as better off than others. As such, whilst social stratifications among the wealthy, the middleincome earners, and the poor, there is no formal class structure in society (Kennedy, 2012). A person's level of education and wealth does not necessarily earn them status or respect; instead it is simply acknowledged that they have an advantage or a 'leg up in life'. Thus, people from different social brackets tend to interact quite easily with each other.

If it is related to the speech delivered by Ardern, it can be seen that the essence of the speech content delivered by Ardern tends to point to facts that have occurred in the field and the steps taken by the government as well as appeals and advice to the public. There were no words from Ardern's speech that boasted of the government's performance and it was clear that Ardern considered the covid-19 policy as a very serious issue. This is related to the culture in New Zealand which is very open minded and respects other people. New Zealand people appreciate the hard work of the government. Also, because there are many New Zealanders with good education, New Zealander can quickly understand the situation so that even though Ardern's words fall into unpleasant facts, New Zealander can accept them well.

In a speech, especially speeches that are delivered by country leaders or political speeches. The ideology, beliefs, and culture of the country are reflected from the speeches. Speeches can be seen as a discourse that has a relation with the context and circumstance. Every leader has a different approach and way of speaking that adapts to the hearer. It is in line with the research conducted by (Hussein, 2016) that proves that the leader's way of speaking is connected to country beliefs and citizen way of view. Leaders usually have distinctive features of speaking and can use language 
tactfully to arrive at the intended goals (Hussein, 2016). (Al-Majali, 2015) also explains that in delivering speeches, every leader has distinctive semantics such as figures of speech; repetition, synonymy and collocation are widely employed in the speech to achieve different political ideologies.

\section{CONCLUSION}

Representative, commissive, and directive illocutionary speech are the forms of speech used in Jacinda Ardern's speech. Her utterances tend to use vocabulary that is straightforward, concise, and easy to understand from the point of view of Fairclough's discourse analysis. She does not use figurative language that could be used to obscure the real meaning of the situation at hand. Her vocabulary appears to be descriptive and to expose details in the field and provide ample context for the potential implications. However, she chose the right words to express her sympathy to minimize people's worries about covid-19. By making a statement about the government's steps to resolve the coronavirus, she can control the overall situation and minimize public concerns.

\section{BIBLIOGRAPHY}

Al-Majali, W. (2015). Discourse Analysis of the Political Speeches of the Ousted Arab Presidents during the Arab Spring Revolution using Halliday and Hasan's Framework of Cohesion. Journal of Education and Practice, Vol. 6 No. 4.

Austin, J. L. (2018). How to Do Things with Words (Paperback edition). New York: Martino Fine Books.

Chaer, A. (2010). Kesantunan Berbahasa. Jakarta: PT Rineka Cipta.

Coulthard, M. (1977). Introduction to Discourse Analysis. London: Longman.

Darma, D. Y. C. (2014) Analisis Wacana Kritis dalam Multiperspektif (Bandung: PT Refika Aditama,

Eriyanto. 2011. Analisis Framing (Kontruksi, Ideologi, dan Politik. Media).Yogyakarta: LKiS.

Fairclough, N. (2013). Political Discourse Analysis: A Method for Advanced Students. London: Routledge.

Fairclough, N., Mulderrig, J., \& Wodak, R. (2013). Critical Discourse Analysis. In T.A Van Dijk (ed). Discourse Studies: A Multidisciplinary Introduction (Online Publication). California: SAGE Publications.

Fairclough, Norman. 1992. Discourse and Social Change. Cambridge: Polity Press.

Gee, J. P. (2011). An Introduction to Discourse Analysis: Theory and Method. New York: Routledge

Graham-McLay, C. (2020). Jacinda Arden's Covid success gives National little room 
to move on policy. https://www.theguardian.com/world/2020/sep/23/jacindaarderns-covid-success-gives-national-little-room-to-move-on-policy

Hossain, M. I. (2015). Teaching productive skills to the students: a secondary level scenario. Thesis, B.A. (English and Humanities). Department of English and Humanities, BRAC University.

Hussein, I. Critical Discourse Analysis of the Political Speech of the Egyptian President, Abdel Fattah El-Sisi, at the New Suez Canal Inauguration Ceremony. International Journal of Language and Literature. Vol. 4, No. 1, pp. 85-106

Kennedy, J. (2012). Leadership and culture in New Zealand. Culture and Leadership Across the World: The Globe Book of In-Depth Studies of 25 Societies. $10.4324 / 9780203936665$.

Kurniati, A. K., Eliwarti, \& Novitri. (2015). A Study On The Speaking Ability Of The Second Year Students Of Smk Telkom Pekanbaru. Jurnal Online Mahasiswa. Vol. 2 No. 2

Leech, G.1996. Prinsip-prinsip pragmatic. Terjemahan M.D.D. Oka. Jakarta: UI Press.

Nunan, D. (2015). Teaching English to Speakers of Other Languages: An Introduction. New York: Routledge.

Rusminto, N. E. (2015). Analisis Wacana Bahasa Indonesia. Bandar Lampung: Universitas Lampung.

Setiadi. 2010. Panduan Penelitian Sosial. Jakarta: Yayasan Lembaga Kemala.

Sharififar, Massoud \& Rahimi, Elaheh. (2015). Critical Discourse Analysis of Political Speeches: A Case Study of Obama's and Rouhani's Speeches at the UN. Theory and Practice in Language Studies. 5. 343. 10.17507/tpls.0502.14.

Van Dijk, T. A. (2014). Discourse and Knowledge: A Sociocognitive Approach. Cambridge: Cambridge University Press.

Wang, J. (2010). A Critical Discourse Analysis of Barack Obama's Speeches. Journal of Language Teaching and Research, Vol. 1, No. 3, pp. 254-261, May 2010

Yule, Y. 1996. Analisis Wacana. Jakarta: Gramedia Pustaka Utama. 